\title{
Abnormities in boy anencephalic newborn in Iran
}

\author{
BAYAT, P. D.* \\ Arak University of Medical Sciences, Central Province - St. Shiroudi - Alam al-Hoda Street, Arak, Iran \\ *E-mail.dr.bayat@arakmu.ac.ir
}

\begin{abstract}
Introduction: Anencephaly is one of the most common neural tube defects. Neural tube defects are birth defects that affect the tissue that grows into the spinal cord and brain. Anencephaly occurs early in the development of an unborn baby. It results when the upper part of the neural tube fails to close. Why this happens is not known. Possible causes include environmental toxins and low intake of folic acid during pregnancy. Anencephaly occurs in about 4 out of 10,000 births. The exact number is unknown, because many of these pregnancies result in miscarriage. Having one infant with this condition increases the risk of having another child with neural tube defects. Materials and Methods \& Results: We report a case anencephaly fetal and his characters in this study from 11543 women in 18 month attending the antenatal clinic (Taleghani gynecology center in Arak city of Iranian center). Conclusion: It is recommended for this fetal disorder, mother ultrasound at from 12 to 20 weeks of pregnancy
\end{abstract}

Keywords: cranium base, enencephaly, neorocranium, ultrasonoghraphy.

\section{Introduction}

Anencephaly is the most frequent lethal embryonic malformation.

Its etiology is still unclear, but certain known factors implicate that it maybe a genetically determined congenital defect (POLMAN, 1950; MOORE and PEERASAUD, 1993; PENROSE, 1957).

The observations indicate that the possible reason for this malformation is the failed closure of the anterior neuropore at 24-26 days post fertilization. Anencephaly is characterized by the absence of the vault and cerebral hemispheres, it is the progression of exencephaly as a consequence of cerebral tissue degeneration and destruction due to mechanical and chemical trauma of the unprotected brain in the amniotic fluid (TICAL, BEGHIM, IRANIA et al., 2009).

\section{Material and Method}

A total of 11543 women in 18 month attending the antenatal clinic (Taleghani gynecology center in Arak city of Iranian center) who were referred for routine USG screening, were included in the study. Among these cases, one case of anencephaly anomalies were detected. We report a case of a 28-year-old, gravid 1, Para 2/0, Fars woman with an anencephalic fetus detected at the 19 th gestational week who opted for continuing the pregnancy for religious reasons. Parents are family and father is self but mother is diploma and she has migren headaches for first trimester and she have BP:130/90 and epigasteric pain in $3 \mathrm{rd}$ trimester. She gives acid folic from 5 -16th weeks of gestation. This pregnant woman comes to perform the ultrasonographic scan of third trimester $(28$ weeks of gestation) showed a single live fetus, with absence of brain and cranial vault, prominent orbits at cranial end giving AF was normal lateral ventricles we re enlargement and shows single ventricle the both thalamus were attachment. It was the purpose to end pregnancy but parents continuing the pregnancy for religious reasons. The investigated fetus was aborted at the Taleghani gynecology Hospital. The neonatal was male and was born in 39 weeks, birth start naturally.

Weight of his was $2600 \mathrm{gr}$ and he was born alive and shoulders get stuck (Figures 1 and 2). 5 minuts after the birth, the newborn suffered an irreversible cardio-respiratory arrest. For a better appreciation of the fetal condition, he was flexed with formaline $10 \%$ and then study his cadaver. The anatomic dissection confirmed:

The spheroidal, temporal and occipital bones showed severe malformations, whereas the bones of the facial cranium were normally developed. Auricles were lower than normal position and angular shap, eye hemi oculud, this haven't spina bifida and menengocele in spinal canal. No arterial circle of Willis was developed. The postcranial parts of the cranial nerves were normally developed. However, the intracranial parts were completely missing. The olfactory nerves were absent.

The optic nerve could be followed up to the optic chiasma where it ended. The peripheral branches of the trigeminal nerve were present with the exception of the ophthalmic division, and its branches.

The neurohypophysis was completely absent, where as the adenohypophysis appeared to be hypertrophic that the bones of the extremities and the trunk were normal and proportional.

\section{Discussion}

Isolated neural-tube defect are, after cardiac defects, the most common congenital structural defects (CUNINGHAM and GANT, 2001).

Anencephaly is the most severe defect from the most common neural-tube anomalies (spina bifida, cephalocele, anencephaly) (CUNINGHAM and GANT, 2001). Embryologic abnormality and the occurrence with a rate of 1:1000 to 1:20 000 infants (ESKES, 1994), in this study the occurrence with a rate of 1:11000. The anencephaly is an infrequent malformation of the central nervous system. It is present at the 28 th day of 


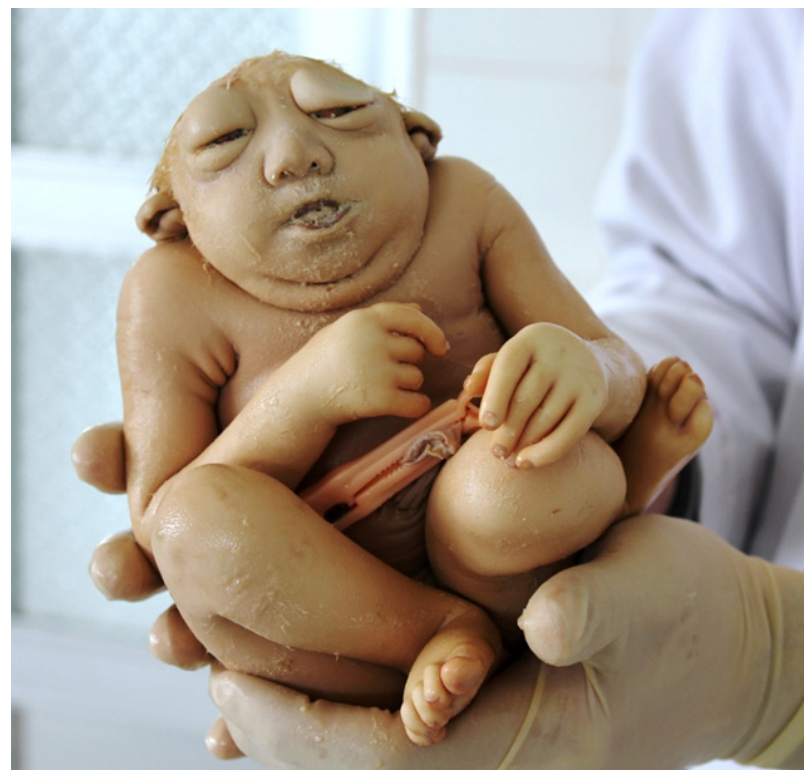

Figure 1. Anencephalic neonatal boy from anterior view.

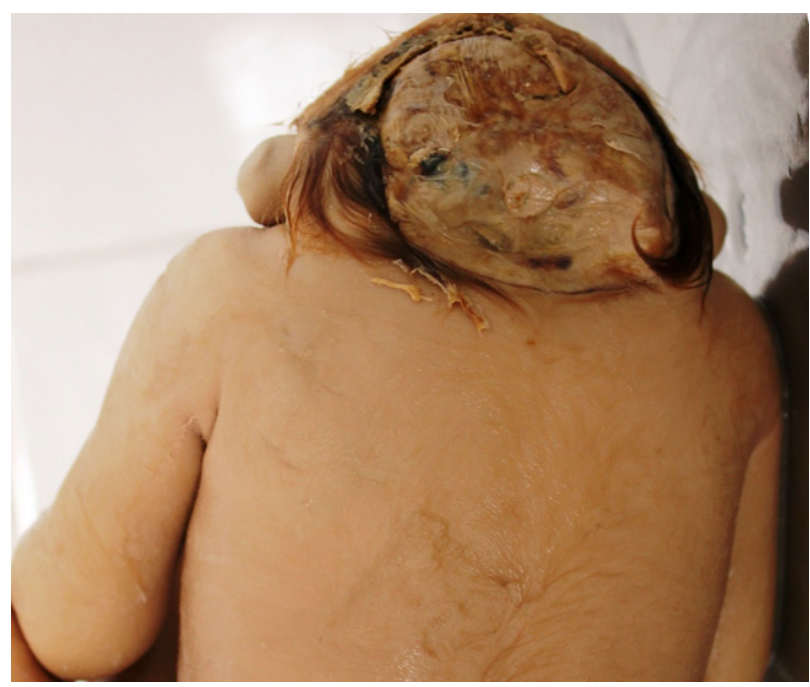

Figure 2. Anencephalic neonatal boy from posterior view.

conception and it is found at the time of birth almost every time. This is why it can be diagnosed by ultrasonography in early stages of pregnancy, even from the $12^{\text {th }}$ week of amenorrhea (STATIANN, 2000). In our case, because of the lack of any examination during the pregnancy, this opportunity was lost and examination was $19^{\text {th }}$ week for first step.

Although the affected foetus in this study was male, anencephaly is clearly not a sex-linked malformation and its aetiology is still being disputed (KASAI, NAKAYAMA, SHIK et al., 1982). There has been no suggestion from any reports so far regarding sex-linked dominance inheritance. There is evidence, however, of a major gene involvement in familial anencephaly with parental consanguinity, and is likely to be recessive in inheritance (SHAFFER, MARAZITA, BODURTHA et al., 1990). A single gene cause of recurrent NTD is the Meckel-Gruber syndrome (TANRIVERDI, HENDRIK, ERTAN et al., 2002). It is a rare autosomal recessive disorder and carries a $25 \%$ risk of recurrence. Other features of this syndromic triad include polycystic kidneys and polydactyly.

In this case despite mother give folate from $5^{\text {th }}$ week to $16^{\text {th }}$ week gestation but not prevention of NTD. Although, Folate supplementation has been shown to halve the risk of foetal NTD (ACOG COMMITTEE OPINION, 1993). Low doses $(400 \mathrm{mcg})$ reduce the risk of first occurrences and high-dose supplementation $(5 \mathrm{mg}$ ) prevents a high proportion of recurrent defects (ESKES, 1994). Ideally, folate supplementation should be started three months preconceptionally in the high-risk population. NTD have also been associated with low concentrations of cobalamin in amniotic fluid (STEEN, BODDIE, FISHER et al., 1998) and both cobalamin and folate may be independent risk factors for neural tube defects.

\section{Conclusion}

The anencephaly is malformation of the central nervous system. This is why it can be diagnosed by ultrasonography in early stages of pregnancy, even from the 12th week of amenorrhea. It is recommended for this fetal disorder, mother ultrasound at from 12 to 20 weeks of pregnancy

\section{References}

ACOG COMMITTEE OPINION. Folic acid for the prevention of recurrent neural tube defects. ACOG Committee Opinion: Committee on obstetrics: maternal and fetal medicine number 120, March 1993. International Journal of Gynaecology and Obstetrics: the Official Organ of the International Federation of Gynaecology and Obstetrics, 1993, vol. 42, p. 75-77. PMid:8103489.

CUNINGHAM, S. and GANT, NF. Williams obstetrics. 21 st ed. New York: McGraw-Hill Professional, 2001. p. 939-971.

ESKES, TK. Possible basis for primary prevention of birth defects with folic acid. Fetal Diagnosis and Therapy, 1994, vol. 9, n. 3, p. 149-154. PMid:8060509. http://dx.doi.org/10.1159/000263923.

KASAI, K., NAKAYAMA, S., SHIK, SS. and YOSHIDA, Y. Sex selection and recurrence of anencephaly. International Journal of Biological Research in Pregnancy, 1982, vol. 3, n. 1, p. 21-24. PMid:6951818.

MOORE, KL. and PEERASAUD, TVN. The developing human: clinically oriented embryology. Philadelphia: W. B. Saunders Company, 1993.

PENROSE, LS. Genetics of anencephaly. Journal of Mental Deficiency Research, 1957, vol. 1, n. 1, p. 4-15. PMid:13491996.

POLMAN, A. Anencephaly, spina bifida and hydrocephaly: a contribution to our knowledge of the causal genesis of congenital malformations. Genetica, 1950, vol. 25, n. 1-2, p. 29-78. PMid:24538475.

SHAFFER, LG., MARAZITA, ML., BODURTHA, J., NEWLIN, A. and NANCE, WE. Evidence for a major gene in familial anencephaly. American Journal of Medical Genetics, 1990, vol. 36, n. 1, p. 97-101. PMid:2333913. http://dx.doi.org/10.1002/ajmg.1320360119.

STATIANN, F. Malformatii congenitale şi afecţiuni fetale. In MUNTEANU, I. (Ed.). Obstetrica. Bucureşti: Academiei Romane, 2000. p. 1016-1042.

STEEN, MT., BODDIE, AM., FISHER, AJ., MACMAHON, W., SAXE, D., SULLIVAN, KM., DEMBURE, PP. and ELSAS, LJ. Neural tube defects are associated with low concentrations of cobalamin (vitamin 12) in amniotic fluid. Prenatal Diagnosis, 1998, vol. 18, n. 6, p. 545-555. PMid:9664599. http://dx.doi.org/10.1002/ (SICI)1097-0223(199806)18:6<545::AID-PD293>3.0.CO;2-2.

TANRIVERDI, HA., HENDRIK, HJ., ERTAN, K. and SCHMIDT, W. Meckel Gruber syndrome: a first trimester diagnosis of a recurrent 
case. European Journal of Ultrasound, 2002, vol. 15, n. 1-2, p. 69-72. PMid:12044856. http://dx.doi.org/10.1016/S0929-8266(02)00009-5.

TICAL, VI., BEGHIM, M., IRANIA, T., ZAHER, M. and ESRA,

B. Anencephaly: pitfalls in pregnancy outcome and relevance of the prenatal exam. Romanian Journal of Morphology and Embryology, 2009, vol. 50, n. 2, p. 295-297. PMid:19434326.

Received September 15, 2015 Accepted November 8, 2016 